\title{
Empirical Analysis of Accounting Information Quality under Financing Constraints
}

\author{
Huiying Fang ${ }^{\mathrm{a}}$, Chubin $\mathrm{Li}^{\mathrm{b}}$ \\ Guangzhou Huali Science and Technology Vocational College, Guangzhou, 511325, China \\ a13538956287@163.com, ${ }^{b} 13539448588 @ 163 . c o m$
}

Keywords: accounting information quality; enterprise performance; financing constraint measurement; multiple regression analysis

\begin{abstract}
The consideration of financing cost may lead to financing difficulties for enterprises. When the internal financing of enterprises is insufficient, the quality of accounting information is seriously affected, in order to quantitatively study the correlation between the quality of accounting information and financing, an empirical analysis model of accounting information quality is proposed based on financing constraint measurement. The explanatory variable model and control variable model of accounting information quality empirical analysis are constructed, and the comprehensive evaluation index system of accounting information quality is constructed according to the financing structure of enterprise. The main variables of accounting information quality are analyzed by descriptive statistical analysis, and the correlation relationship between accounting information quality and enterprise performance is analyzed by correlation analysis and multivariate regression analysis. The earnings quality barrier index, growth index and income security index are constructed, KMO test of SPSS 20.0 software and Bartlett spherical statistics are used to judge accounting information quality under financing constraint measure, and improve the diagnosis result of enterprise accounting information quality. The results of empirical analysis show that the confidence level of the empirical analysis of accounting information quality using this model is high, which helps enterprises to evaluate financing mode and performance objectively and fairly while improving the quality of accounting information, their own operation and management efficiency are improved.
\end{abstract}

\section{Introduction}

Financing has always been one of the important contents of financial management research. Enterprises are faced with many financing channels, but the most concern of enterprises is not where the money comes from, but the price paid for obtaining funds, that is, the cost of financing. The consideration of financing cost may lead to financing difficulties. When the internal financing of the enterprise is insufficient and the external financing is hindered, the enterprise has to give up some valuable investment projects, the enterprise will be faced with a certain degree of financing constraints. When the degree of financing constraint is large enough, it will lead to a series of consequences, the most serious is enterprise bankruptcy. Therefore, what are the factors that affect 
the financing constraints? How to avoid financing constraints? The research on financing constraints is highly concerned by the theoretical and practical circles ${ }^{[1]}$.

Enterprises are faced with financing constraints caused by a variety of factors, at present, with the rapid development of capital market, the role of enterprise accounting information gradually appears. The true and fair accounting information, as an important guarantee of rational allocation of market resources, is an important basis for the high efficiency of government macro-control ${ }^{[2]}$. However, there are still some problems in accounting information management. The pressure of enterprise performance is one of the main reasons that lead to accounting information distortion ${ }^{[3]}$. It is found that most of the enterprises with accounting information quality problems are in the state of loss or the trend of loss. A considerable number of enterprises with good quality management of accounting information also have the problem of accounting information distortion and the poor performance of the various characteristics, which is due to the weak links in the aspects of financial management, accounting and accounting, the implementation of fiscal and taxation policies and internal control, and so on. In this paper, an empirical analysis model of accounting information quality based on financing constraint measure is proposed. The main variables of accounting information quality are analyzed by descriptive statistical analysis method, and the accounting information quality under financing constraint measure is judged by KMO test of SPSS 20.0 software and Bartlett spherical statistics ${ }^{[4]}$. Improve the quality of accounting information diagnostic results. Finally, the empirical results show the superiority of this method in improving the confidence level of accounting information quality platform.

\section{Evaluation index system and sample selection of accounting information quality}

\subsection{Theoretical basis of accounting information quality}

Accounting information refers to the information that an enterprise reveals to investors, creditors or other information users through financial statements, financial reports or notes ${ }^{[5]}$. Accounting information includes financial accounting information and management accounting information. Financial accounting information is the more basic accounting information in the daily operation and management of enterprises ${ }^{[6]}$. Under the financing constraint measure, the characteristic measure methods of accounting information quality are expressed as follows:

(1) The method of measuring the overall quality of accounting information. Taking earnings quality as the representative of the overall quality of accounting information, the methods of evaluating earnings quality can be summarized into two categories: one is to construct the barrier index of earnings quality, the growth index and the security index of earnings; the other is the quality evaluation based on the influencing factors of earnings quality. Fixed model. Loss recognition timeliness is an important factor affecting earnings quality.

(2) Measuring the quality characteristics of accounting information. At present, reliability and relevance are the most commonly used methods to evaluate the quality of accounting information. The accounting information should be the decision service made by the users of accounting information, so as to give full play to its value of verification and prediction.

\subsection{Analysis of variance}

From the research on the quality characteristics of accounting information and the evaluation methods of accounting information quality, the most important thing for accounting information users is the relativity and reliability of enterprise accounting information quality. Based on the data law of accounting information itself, this paper puts forward an evaluation method of accounting information quality based on Benford's law, taking the accounting information data of enterprises as 
the research object. The quality of accounting information is evaluated according to the degree of agreement between the first digital distribution of accounting information data and the theoretical distribution of Benford's law. In essence, the evaluation method proposed in this paper is to test the reliability of accounting information data and to confirm the importance that accounting information users attach to reliability ${ }^{[7]}$. Under the measure of financing constraint, the explanatory variable model and control variable model of accounting information quality empirical analysis are constructed. The variable definition of accounting information quality evaluation is shown in Table 1.

Table 1 Variable setting

\begin{tabular}{|c|c|c|c|}
\hline $\begin{array}{l}\text { Type } \\
\text { variable }\end{array}$ & Variable name & $\begin{array}{l}\text { Variable } \\
\text { code }\end{array}$ & Variable definition \\
\hline \multirow[t]{2}{*}{$\begin{array}{l}\text { Explanatory } \\
\text { variable }\end{array}$} & $\begin{array}{l}\text { Financing decision } \\
\text { effectiveness }\end{array}$ & FME & $\begin{array}{l}\text { The correlation between the quality of Accounting } \\
\text { Information and Enterprise performance }\end{array}$ \\
\hline & Financing mode & FM & $\begin{array}{l}\text { They are double financing, single share financing, } \\
\text { endogenous financing, P2P financing and so on. }\end{array}$ \\
\hline \multirow[t]{2}{*}{$\begin{array}{l}\text { Explained } \\
\text { variable }\end{array}$} & $\begin{array}{l}\text { Corporate } \\
\text { capital }\end{array}$ & SC & $\begin{array}{l}\text { The relationship between Internal Corporate } \\
\text { Governance Index and Accounting Information } \\
\text { quality }\end{array}$ \\
\hline & $\begin{array}{l}\text { Financing } \\
\text { relevance }\end{array}$ & PC & $\begin{array}{l}\text { Financing policy, CBRC policy, board of directors } \\
\text { policy, policy promotion value is } 1 \text {, otherwise } 0\end{array}$ \\
\hline \multirow[t]{4}{*}{$\begin{array}{l}\text { Controlled } \\
\text { variable }\end{array}$} & $\begin{array}{l}\text { Internet supply chain } \\
\text { scale }\end{array}$ & Size & Total assets and turnover of enterprises \\
\hline & $\begin{array}{l}\text { Market value and } \\
\text { book value ratio }\end{array}$ & MB & $\begin{array}{l}\text { Multivariate statistical analysis of accounting } \\
\text { information quality }\end{array}$ \\
\hline & Asset-liability ratio & ALR & $\begin{array}{l}\text { Total assets / corporate financing liabilities at } \\
\text { maturity }\end{array}$ \\
\hline & Operating leverage & OL & $\begin{array}{l}\text { Rate of change in pre-tax profits / total corporate } \\
\text { income }\end{array}$ \\
\hline
\end{tabular}

\section{Construction of mathematical model for evaluating the quality of accounting information}

\subsection{Analysis on the correlation between the measure of financing constraint and the quality of accounting information}

On the basis of constructing the explanatory variable model and control variable model of accounting information quality empirical analysis, the comprehensive evaluation index system of accounting information quality is carried out according to the financing structure of the enterprise ${ }^{[8]}$. In the multi-dimensional management accounting system, the fixed effect evaluation decision function of accounting information quality evaluation under the measurement of external quality and financing constraints is obtained by using the method of objective capital structure regression analysis:

$$
x_{n}=a_{0}+\sum_{i=1}^{M_{A R}} a_{i} x_{n-i}+\sum_{j=0}^{M_{M A}} b_{j} \eta_{n-j}
$$

Where, the decision variable function of accounting information quality evaluation contains $n$ fictitious sample of debt financing, in which the internal control sample of enterprise financing risk $x_{i}, i=1,2, \cdots, n, \quad a_{0}$ represents the financial evaluation index system of enterprise operation performance, and $a_{i}$ is excessive financing coefficient. $M_{A R}$ is the order of accounting 
information distortion, and $\eta_{n-j}$ is the time interval of data sampling ${ }^{[9]}$. The game control function for obtaining monthly financing of enterprise accounting information is described as follows:

$$
S(i, j)=\frac{\sum_{u \in U_{i j}}\left(V_{u, i}-3\right)\left(V_{u, j}-3\right)}{\sqrt{\sum_{u \in U_{i j}}\left(V_{u, i}-\overline{V_{i j}}\right)^{2}} \sqrt{\sum_{u \in U_{i j}}\left(V_{u, j}-\overline{V_{. j}}\right)^{2}}}
$$

According to the chi-square test results of the first digital distribution of the financial data set and the theoretical distribution of Benford's law, the smaller the statistical value of chi-square test, the smaller the statistical value of chi-square test. It shows that the better the consistency between the first digital distribution of financial data and the theoretical distribution of Benford's law, the better, and the better the degree of agreement between the first digital distribution and the theoretical distribution of Benford's law is, and the regression coefficient of the whole sample is set as $Y$. A regression analysis model of financing constraint and accounting information quality evaluation is established by obtaining accounting information quality evaluation index set $E_{\mathrm{k}} \in E(k=1,2, \ldots, t)$, as:

$$
Q=\frac{C_{1} \sum_{i=1}^{k} \exp \left[-S_{2}\left(V_{i}-\mu\right)^{2}\right]}{1+\exp \left[-S_{1} \sum_{i=1}^{k} w_{i}\left(T_{i}-V_{i}\right)\right]}
$$

According to the degree of deviation between the financial data digital distribution and the theoretical distribution of Benford's law, the internal quality control and the adaptive adjustment of the financing quota are carried out to improve the enterprise performance under the maximum return on capital level.

\subsection{Evaluation model of accounting information quality}

Correlation analysis and multiple regression analysis are used to analyze the correlation between accounting information quality and enterprise performance, and the net profit margin of assets is taken as the constraint statistical variable ${ }^{[10]}$. The optimization model of accounting information quality evaluation for enterprises under financing mode is obtained as follows:

$$
\min _{\omega, h, \zeta_{l}, \zeta_{l}^{*}}=\frac{1}{2} \omega^{T} \omega+c \sum_{i=1}^{l}\left(\zeta_{l}+\zeta_{l}^{*}\right)
$$

In the formula, $\zeta_{l}$ and $\zeta_{l}$ denote relaxation variables, $\zeta_{l}$ denotes industry virtual variables, and $c$ denotes digital distribution set of financial data. The fuzzy comprehensive decision function of accounting information quality evaluation is constructed by factor analysis fuzzy comprehensive evaluation method:

$$
\mu_{B_{i}}=a_{B_{i}}+b_{B_{i}} \Delta+c_{B_{i}} \Phi
$$

The factor analysis method is used to calculate the performance score of the enterprise, and there is no correlation between the public factors extracted. According to the comprehensive evaluation decision function, the reliability level of the evaluation results is obtained as follows:

$$
f(x)=\sum_{i=1}^{l}\left(a_{i}+a_{i}^{*}\right) k\left(x-x_{i}\right)+b
$$

According to the financing structure of the enterprise, the financial leverage is used to construct the comprehensive evaluation index system of accounting information quality, and the constraint 
parameter model is established, and the principal component characteristic analysis model of quantitative evaluation of accounting information quality is obtained as follows:

$$
\min _{0 \leq \alpha_{i} \leq C} W=\frac{1}{2} \sum_{i, j=1}^{l} y_{i} y_{j} \alpha_{i} \alpha_{j} K\left(x_{i}, x_{j}\right)-\sum_{i=1}^{l} \alpha_{i}+b\left(\sum_{i=1}^{l} y_{j} \alpha\right)
$$

The linear regression model is constructed by removing the redundant information and combining the autocorrelation characteristic analysis method with the method of heavy weight index. The expression is described as follows:

$$
f(x)=\omega^{T}(\phi)_{X}+b
$$

According to the above mathematical model and the method of factor analysis, the quantitative evaluation of accounting information quality under the measurement of financing constraints is realized.

\section{Empirical results and analysis}

This paper uses factor analysis method to evaluate the operating performance of 21 cities in Guangdong from 2011 to 2017. Business performance evaluation includes four parts: the selection of evaluation index, the processing of evaluation index data, the analysis of evaluation index factor, the analysis of performance evaluation result. The factor analysis of performance evaluation index includes the following three steps: Test the suitability of factor analysis in the evaluation index system, and to determine whether some evaluation indexes are suitable for factor analysis to construct common factor variables. Calculate the characteristic value, the characteristic contribution rate and the accumulative contribution rate. Calculate the factor score and the performance synthesis score.

In this paper, we use the KMO test of SPSS 20.0 software and Bartlett spherical statistics to judge whether the evaluation index system of enterprise performance benefit value class is suitable for factor analysis.

Multiple regression analysis is used to analyze the factor analysis results of accounting information quality evaluation under financial constraint measurement, as shown in figure 1 .

Figure 1 shows that the empirical evaluation of accounting information quality by using this model shows that the financial risk is decreasing, and the probability that accounting information quality is not related to enterprise performance is less than 0.05 . The quality of accounting information is evaluated by Pearson product correlation method. The results of regression analysis of all models are shown in figure 2. Figure 2 shows that the model of accounting information quality evaluation designed in this paper has a high correlation at the level of $5 \%$ significance, and the confidence level of the evaluation results is higher. The quality of accounting information and the change of performance show the opposite trend. The annual trends of accounting information quality and performance change tend to converge, which may be due to the following reasons: first, the quality of accounting information managers is on the low side, and there is "unintentional distortion" behavior in daily operation. As a result, the quality of accounting information is low, which affects the effectiveness of the decision-making of local and municipal company managers, and then affects the realization of the performance of prefectures and cities. Secondly, the characteristics of prefectures, such as the scale of users, the degree of development of other performance factors are not as good as other cities, so in the case of the same performance evaluation rules, the performance of this kind of cities is not good. 


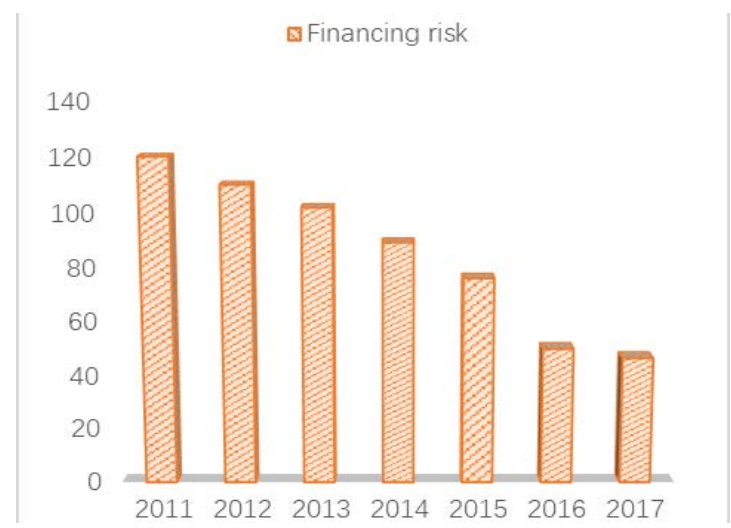

Figure 1. Results of financial measurement factor analysis

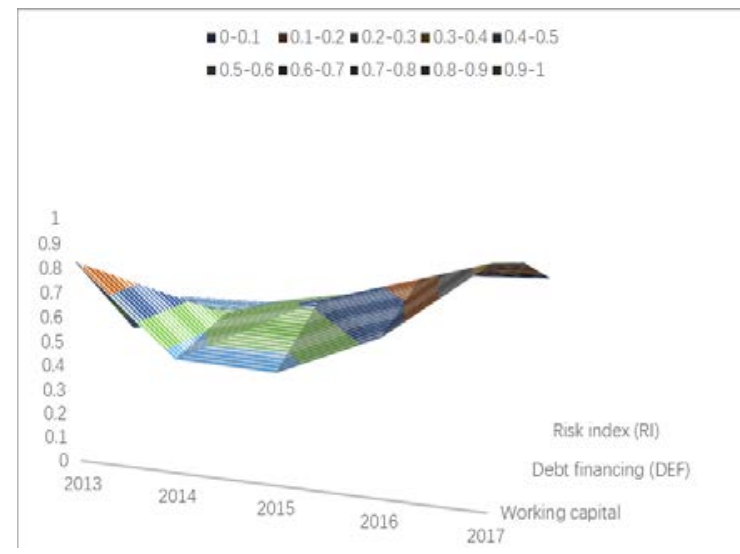

Figure 2. Results of regression analysis of accounting information quality

\section{Conclusions}

With the development of market economy, the problem of information asymmetry is becoming more and more serious. Therefore, the management of enterprises pay more and more attention to the quality of accounting information. In this paper, an empirical analysis model of accounting information quality based on financing constraint measurement is proposed. The method of statistical analysis is used to judge the quality of accounting information under the measure of financing constraints and to improve the diagnostic results of enterprise accounting information quality. The results of empirical analysis show that the confidence level of the empirical analysis of accounting information quality using this model is high, which helps enterprises to evaluate financing mode and performance objectively and fairly while improving the quality of accounting information. This method has a good application value in accounting information quality evaluation.

\section{References}

[1] BAI Xuejie, SUN Hongyin, WANG Haifeng. M\&A Behaviors and Market Power; An Analysis Based on Chinese A-share Enterprises[J]. Contemporary economic science,2016, (03):106-113.

[2] Aslanidis N, Christiansen C. Smooth Transition Patterns in the Realized Stock-bond Correlation[J]. Journal of Empirical Finance, 2012, 19(4):454-464.

[3] PAN Jizheng. Improvement of accounting method of large scientific research project based on Evolutionary Game Theory[J]. Management Engineer, 2017,22(1):36-40.

[4] ZHAO Xiaolin, WU Yipeng, HUANG Huiying, et al. New generation of migrant workers housing purchasing power and the housing sales to inventory constraints relationship model -- Taking Zengcheng area as an example[J]. 
Management Engineer, 2017,22(1):8-13.

[5] YAO Lei, YAO Wang Xin. Research on the policy effect of incremental expansion of margin and securities lending: Based on the multi period DID model and Hausman's test [J]. international financial research, 2016, 349 (5): 85-96.

[6] Don M. Autore, Randall S. Billingsley, Tunde Kovacs. The 2008 Short Sale Ban: Liquidity, Dispersion of Opinion, and the Cross-section of Returns of US Financial Stocks[J]. Journal of Banking \&\#x00026.Finance,2011,35(9):2252-2266.

[7] ALESSANDRO BEBER, MARCO PAGANO. Short-Selling Bans around the World: Evidence from the 2007-09 Crisis [J]. Journal of Finance,2013,68(1):343-381.

[8] MIN BAI, YAFENG QIN. Short-sales Constraints and Liquidity Change: Cross-sectional Evidence from the Hong Kong Market[J]. Pacific-Basin Finance Journal,2014,26:98-122.

[9] OLESYA LOBANOVA, SHAHID S. HAMID, ARUN J. PRAKASH. Shot Sales Ban and Stock Market Liquidity: The Comparison of NYSE and NASDAQ-Listed Stocks[J]. International Journal of Finance,2011,23(2):6750-6763.

[10]WEI Wei, JIANG Hai, PANG Sulin. Monetary policy, regulatory policy and bank credit behavior -- An Empirical Study Based on China's banking industry analysis (2002-2012) [J]. International finance research ,2016, 349 (5): 48-60. 